\title{
DICYCLOPENTADIENYLTITANIUM(IV) PYRIDINE-2,6-DICARBOXYLATE COMPLEXES. SYNTHESIS AND STRUCTURAL CHARACTERIZATION AS PENTACOORDINATE TITANOCENE DERIVATIVES
}

\author{
REGINA LEIK, LASZLO ZSOLNAI, GOTTFRIED HUTTNER, EBERHARD W. NEUSE \\ and HANS H. BRINTZINGER *
}

Fakultät für Chemie, Universität Konstanz (F.R.G.)

\section{Summary}

Reaction of $\left(\mathrm{C}_{5} \mathrm{H}_{5}\right)_{2} \mathrm{Ti}\left(\mathrm{CH}_{3}\right)_{2}$ or $\left(\mathrm{CH}_{3}\right)_{4} \mathrm{C}_{2}\left(\mathrm{C}_{5} \mathrm{H}_{4}\right)_{2} \mathrm{Ti}\left(\mathrm{CH}_{3}\right)_{2}$ with pyridine-2,6dicarboxylic acid (dipicolinic acid) yields titanocene dipicolinate derivatives. The molecular structure of $\left(\mathrm{C}_{5} \mathrm{H}_{5}\right)_{2} \mathrm{Ti}$ dipicolinate is that of an axially symmetric, pentacoordinate titanocene derivative with two carboxyl oxygen atoms and the pyridine nitrogen atom as ligating atoms. Two identical chelate bite angles of only $71^{\circ}$ make the dipicolinate ligand particularly suited to form a remarkably stable titanocene derivative with unprecedented pentacoordinate geometry.

\section{Introduction}

The molecular structures of a vast number of dicyclopentadienyltitanium(IV) compounds studied to date have invariably revealed a tetracoordinate, pseudotetrahedral coordination geometry $* *$. These species thus have a 16 -valence electron configuration with an unoccupied coordination site available, e.g., for associative reaction steps. Stable pentacoordinate species similar to those well known for other Group IV to VI transition metals [6-11], however, have not previously been observed in any structurally characterized titanocene derivative ${ }^{* * *}$.

* To whom correspondence should be addressed.

** Cf. ref. 1 and references therein. At the titanium-(II) and -(III) levels, titanocene derivatives with tricoordinate geometry have been reported in a few instances [2-5].

*** Whether complexes with $\eta^{2}$-coordinated ligands, such as $\left(\mathrm{C}_{5} \mathrm{H}_{5}\right)_{2} \mathrm{Ti}(\mathrm{CO}) \mathrm{C}_{2}\left(\mathrm{C}_{6} \mathrm{H}_{5}\right)_{2}$ [12] or $\left(\mathrm{C}_{5} \mathrm{H}_{5}\right)_{2} \mathrm{Ti}(\mathrm{Cl}) \mathrm{OCCH}_{3}$ [13] should be considered as examples of pseudotetrahedral geometry or as exceptions to this rule is debatable. In a number of instances, pentacoordinate or hexacoordinate dicyclopentadienyltitanium(IV) species have been proposed without support from crystal structure determinations [14-19]. 
In this communication, we report on the synthesis and structural characterization of pentacoordinate titanocene derivatives containing the dipicolinate (pyridine-2,6dicarboxylate, denoted by dipic) ligand.

\section{Results and discussion}

Reaction of dimethyltitanocene, $\left(\mathrm{C}_{5} \mathrm{H}_{5}\right)_{2} \mathrm{Ti}\left(\mathrm{CH}_{3}\right)_{2}$, with dipicolinic acid in tetrahydrofuran leads, after evaporation of solvent and subsequent recrystallization from toluene/hexane, in about $60 \%$ theoretical yield, to a yellow, microcrystalline material with elemental composition and ${ }^{1} \mathrm{H}$ NMR spectrum (see Table 1) in accord with a complex of composition $\left(\mathrm{C}_{5} \mathrm{H}_{5}\right)_{2} \mathrm{Ti}$ (dipic). The material is readily soluble in methylene dichloride, diethyl ether, or toluene*. Slow evaporation from chloroform solution gave crystals suitable for an X-ray crystal structure determination.

Analogous results were obtained when the tetramethylethylene-bridged dimethyltitanocene derivative, $\left(\mathrm{CH}_{3}\right)_{4} \mathrm{C}_{2}\left(\mathrm{C}_{5} \mathrm{H}_{4}\right)_{2} \mathrm{Ti}\left(\mathrm{CH}_{3}\right)_{2}$, was treated with dipicolinic acid in tetrahydrofuran. The ${ }^{1} \mathrm{H}$ NMR spectrum of the product showed the signals from the cyclopentadienyl protons as two pseudotriplets, indicating a structure which is axially symmetric on the ${ }^{1} \mathrm{H}$ NMR time scale (Table 1 ).

For a structural characterization of $\left(\mathrm{C}_{5} \mathrm{H}_{5}\right)_{2} \mathrm{Ti}$ (dipic), space group, cell parameters and X-ray diffraction intensities were determined on a Syntex-P3 four-circle diffractometer at $243 \mathrm{~K}$, using Mo- $K_{\alpha}$ radiation $(\lambda 0.71069 \AA$ ), graphite monochromator, $\omega$-scan with $1.8<\dot{\omega}<24.3^{\circ} \min ^{-1}, \Delta \omega 1.2^{\circ}$ and $2 \leq 2 \theta \leq 46^{\circ}$. The space group was found to be $P 4_{3} 2_{1} 2$, with 4 crystallographically equivalent molecules per unit cell. Cell parameters: $a=b=775.7(4), c=2239(2) \mathrm{pm} ; \alpha=\beta=\gamma=90^{\circ} ; V$ $1348 \times 10^{6} \mathrm{pm}^{3} ; d_{\text {calcd }} 1.69 \mathrm{~g} / \mathrm{cm}^{3}$; absorption coefficient $\mu 6.9 \mathrm{~cm}^{-1}$. For solution and refinement of the structure, 867 independent reflexes with $I \geq 2 \sigma(I)$ were used; empirical absorption corrections were applied.

\section{TABLE 1}

${ }^{1} \mathrm{H}$ NMR SPECTRA OF $\left(\mathrm{C}_{5} \mathrm{H}_{5}\right)_{2}$ Ti(dipic) AND $\left(\mathrm{CH}_{3}\right)_{4} \mathrm{C}_{2}\left(\mathrm{C}_{5} \mathrm{H}_{4}\right)_{2} \mathrm{Ti}$ (dipic) IN $\mathrm{CDCl}_{3}$ SOLUTION AT $250 \mathrm{MHz}\left({ }^{1} \mathrm{H}\right.$ NMR shifts in ppm relative to TMS)

\begin{tabular}{|c|c|c|c|c|}
\hline \multicolumn{2}{|c|}{$\left(\mathrm{C}_{5} \mathrm{H}_{5}\right)_{2} \mathrm{Ti}$ (dipic) } & \multicolumn{2}{|c|}{$\left(\mathrm{CH}_{3}\right)_{4} \mathrm{C}_{2}\left(\mathrm{C}_{5} \mathrm{H}_{4}\right)_{2} \mathrm{Ti}(\mathrm{dipic})$} & \multirow[t]{2}{*}{ Assignment } \\
\hline Shift & Intensity & Shift & Intensity & \\
\hline \multirow[t]{2}{*}{6.22} & $10(s)$ & 1.61 & $12(s)$ & $\begin{array}{l}\left(\mathrm{CH}_{3}\right)_{4} \mathrm{C}_{2} \\
\mathrm{C}_{5} \mathrm{H}_{5}\end{array}$ \\
\hline & & $\begin{array}{l}5.77 \\
6.22\end{array}$ & $\begin{array}{l}4(\mathrm{t}, 2.6 \mathrm{~Hz}) \\
4(6,2.6 \mathrm{~Hz})\end{array}$ & $\mathrm{C}_{5} \mathrm{H}_{4}$ \\
\hline 8.28 & $3(\mathrm{~m})^{a}$ & 8.26 & $3(\mathrm{~m})^{u}$ & $\mathrm{NC}_{5} \mathrm{H}_{3}$ \\
\hline
\end{tabular}

${ }^{a}$ The signals of the pyridine $\mathrm{H}$ atoms are only partly resolved and have the appearance of a broadened singlet.

* Other methods commonly employed for the synthesis of titanocene dicarboxylate complexes, such as reaction of $\left(\mathrm{C}_{5} \mathrm{H}_{5}\right)_{2} \mathrm{TiCl}_{2}$ with free carboxylic acid in the presence of triethylamine, or with two equivalents of sodium carboxylate, e.g. in ethanol solution (cf. ref. 1 and literature cited there), in the case of dipicolinic acid or its disodium salt gave mainly products insoluble in $\mathrm{CHCl}_{3}$ or THF (which were probably polymeric species and could not be characterized) and only small quantities of $\left(\mathrm{C}_{5} \mathrm{H}_{5}\right)_{2} \mathrm{Ti}$ (dipic). 
TABLE 2

STRUCTURAL PARAMETERS FOR $\left(\mathrm{C}_{5} \mathrm{H}_{5}\right)_{2}$ Ti DIPICOLINATE FRACTIONAL COORDINATES (with e.d.s.'s and isotropic thermal parameters)

\begin{tabular}{lllll}
\hline Atom & \multicolumn{1}{l}{$x$} & $y$ & $z$ & $U$ \\
\hline $\mathrm{Ti}$ & $0.2632(2)$ & $0.7369(2)$ & 0.25000 & \\
$\mathrm{~N}$ & $0.4601(8)$ & $0.5399(8)$ & 0.25000 & \\
$\mathrm{C}(1)$ & $0.081(1)$ & $0.527(1)$ & $0.2950(4)$ & $0.037(2)$ \\
$\mathrm{C}(2)$ & $0.046(1)$ & $0.527(1)$ & $0.2343(4)$ & $0.038(3)$ \\
$\mathrm{C}(3)$ & $-0.023(1)$ & $0.692(1)$ & $0.2192(4)$ & $0.034(2)$ \\
$\mathrm{C}(4)$ & $-0.032(1)$ & $0.785(1)$ & $0.2728(4)$ & $0.035(2)$ \\
$\mathrm{C}(5)$ & $0.033(1)$ & $0.687(1)$ & $0.3169(4)$ & $0.036(2)$ \\
$\mathrm{C}(6)$ & $0.545(1)$ & $0.509(1)$ & $0.2995(4)$ & $0.022(2)$ \\
$\mathrm{C}(7)$ & $0.677(1)$ & $0.384(1)$ & $0.3015(4)$ & $0.030(2)$ \\
$\mathrm{C}(8)$ & $0.708(1)$ & $0.292(1)$ & 0.250000 & $0.032(3)$ \\
$\mathrm{C}(9)$ & $0.493(1)$ & $0.616(1)$ & $0.3502(4)$ & $0.022(2)$ \\
$\mathrm{O}(1)$ & $0.3631(7)$ & $0.7123(8)$ & $0.3373(3)$ & \\
$\mathrm{O}(2)$ & $0.5668(8)$ & $0.6119(8)$ & $0.3976(3)$ & \\
\hline
\end{tabular}

TABLE 3

BOND LENGTHS (pm) AND BOND ANGLES $\left(^{\circ}\right)$ AT THE Ti ATOM IN $\left(\mathrm{C}_{5} \mathrm{H}_{5}\right)_{2}$ Ti DIPICOLINATE $\left(C R=\right.$ centroid of $C_{5}$ ring; $P L=$ mean plane of $C_{5}$ ring)

\begin{tabular}{lllc}
\hline Ti-O & $211.1(6)$ & O-Ti-N & $71.1(2)$ \\
Ti-N & $216.0(8)$ & CR-Ti-CR' & 133.0 \\
Ti-CR & 205.2 & PL-PL' & 47.2 \\
Ti-PL & 205.2 & & \\
Ti-C(1) & $238(1)$ & & \\
Ti-C(2) & $237(1)$ & & \\
Ti-C(3) & $235(1)$ & & \\
Ti-C(4) & $238(1)$ & & \\
Ti-C(5) & $236(1)$ & & \\
\hline
\end{tabular}

The structures were solved by direct methods (SHELXTL) and refined with a partially anisotropic model, using a weighting scheme based on counting statistics. Hydrogen atom positions were taken from the Fourier difference map, but not refined. The refinement converged at $R_{1}=0.0773$ and $R_{2}=0.084$, where $R_{1}=$ $\left(\Sigma\left\|F_{\mathrm{o}}|-| F_{\mathrm{c}}\right\|\right) / \Sigma\left|F_{\mathrm{o}}\right|$ and $R_{2}=\left[\Sigma \omega\left(\left|F_{\mathrm{o}}\right|-\left|F_{\mathrm{c}}\right|\right)^{2}\right]^{1 / 2} /\left[\Sigma \omega\left|F_{\mathrm{o}}\right|^{2}\right]^{1 / 2}$. Relevant bond lengths and bond angles are listed in Table $3 *$.

The molecular structure of $\left(\mathrm{C}_{5} \mathrm{H}_{5}\right)_{2} \mathrm{Ti}$ (dipic) (see Fig. 1) is that of an axially symmetric, pentacoordinate metallocene derivative; the Ti atom and the pyridine atoms $\mathrm{N}$ and $\mathrm{C}(8)$ are located on a crystallographic $C_{2}$ axis. The cyclopentadienyl centroids are at a distance of $205.2 \mathrm{pm}$ from the Ti centre and span an angle of $133.0^{\circ}$ at the $\mathrm{Ti}$ atom, the two cyclopentadienyl planes intersecting at an angle of $47.2^{\circ}$. This $\left(\mathrm{C}_{5} \mathrm{H}_{5}\right)_{2} \mathrm{Ti}$ geometry is almost indistinguishable from that of normal tetracoordinate derivatives, such as $\left(\mathrm{C}_{5} \mathrm{H}_{5}\right)_{2} \mathrm{TiCl}_{2}[20]$.

\footnotetext{
* Detailed structural data are available on request from Fachinformationszentrum Energie Physik Mathematik, D-7514 Eggenstein-Leopoldszentrum 2, by citing of deposit. No. CSD 52002, the authors and the journal reference for this article.
} 

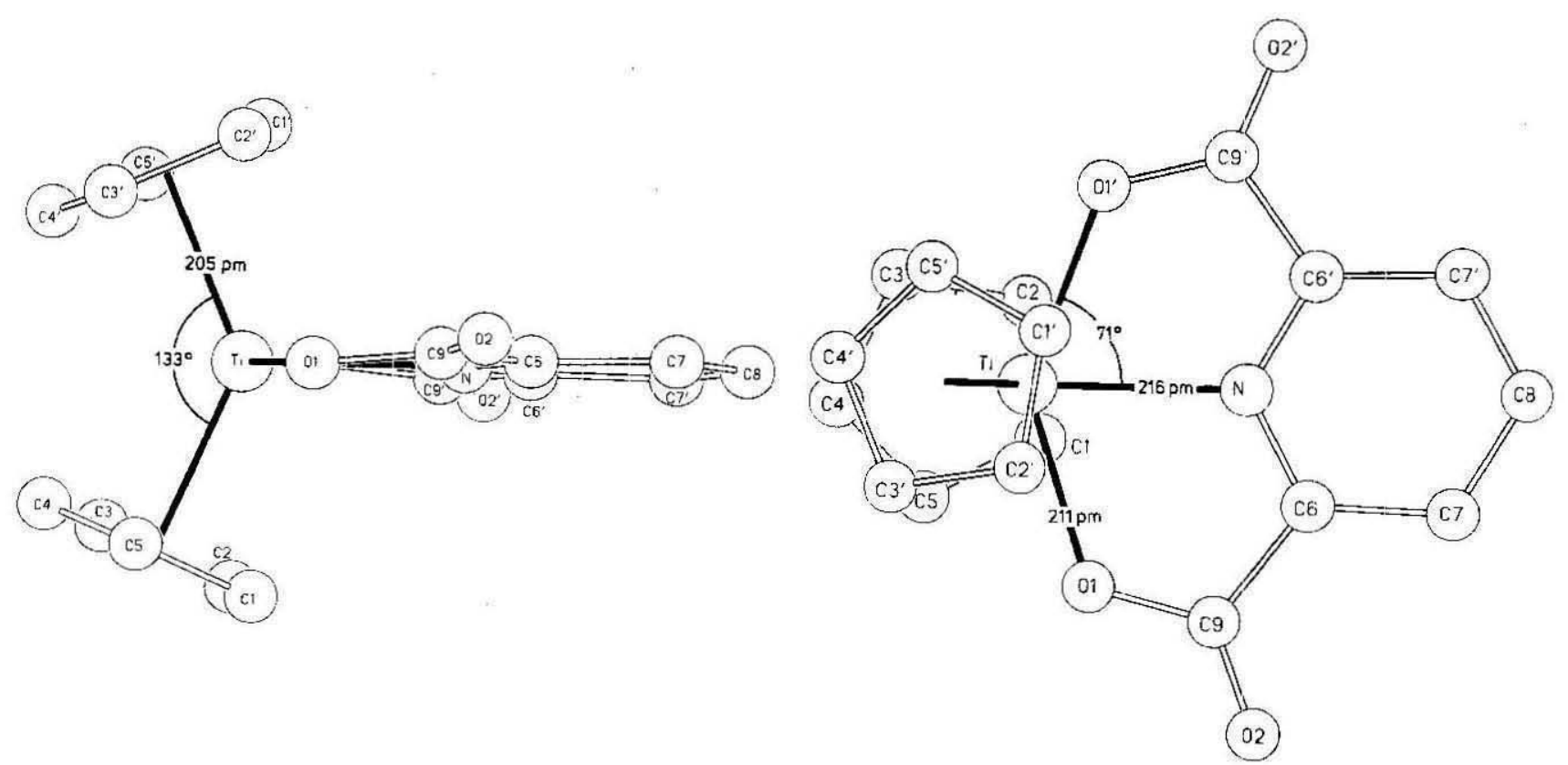

Fig. 1. Molecular structure of $\left(\mathrm{C}_{5} \mathrm{H}_{5}\right)_{2} \mathrm{Ti}$ dipicolinate. Projection on to the plane containing the $\mathrm{C}_{5} \mathrm{H}_{5}$-ring centroids, the $\mathrm{N}$ atom and the Ti centre (left) and onto the $\mathrm{TiO}(1) N O\left(1^{\prime}\right)$ ligand plane perpendicular to it (right). 
As expected from structural studies on other transition metal dipicolinate complexes [21-25], the dipicolinate ligand is bound to the Ti centre by its pyridine $\mathrm{N}$ atom and two of the carboxylate $\mathrm{O}$ atoms, which occupy the central and the two lateral coordination sites of the titanocene fragment. The Ti-N and Ti-O distances of 216 and $211 \mathrm{pm}$ are significantly longer than $\mathrm{Ti}-\mathrm{N} \equiv$ bonds $(196-202 \mathrm{pm})$ $[2,26,27]$ and Ti-O bonds $(186-190 \mathrm{pm})[28-30]$ in comparable, tetracoordinate titanocene complexes. The $\mathrm{O}-\mathrm{Ti}-\mathrm{N}$ angle of $71.1^{\circ}$ is within the range of $65-73^{\circ}$ found for other pentacoordinate, non-hydridic metallocene derivatives [10,11].

The Ti centre and its $\mathbf{N}$ and $\mathbf{O}$ ligand atoms are coplanar by crystal symmetry; the $\operatorname{TiO}(1) \mathrm{NO}\left(1^{\prime}\right)$ plane is perpendicular to the ring centroid-Ti-centroid plane: the two planes intersect at an angle of $89.9^{\circ}$. Interestingly, the plane of the pyridine ring is not quite coplanar with the $\operatorname{TiO}(1) \mathrm{NO}\left(1^{\prime}\right)$ plane: A slight rotational deviation of these two planes by $3.6^{\circ}$ is connected with a rotation of both $\mathrm{CO}_{2}$ groups by $4.8^{\circ}$ out of plane of the pyridine ring, and by $7.4^{\circ}$ out of the $\operatorname{TiO}(1) \mathrm{NO}\left(1^{\prime}\right)$ plane. A similar deviation from coplanarity, which will lead to a slight shortening of the $\mathrm{Ti}-\mathrm{N}$ relative to the two $\mathrm{Ti}-\mathrm{O}$ distances, with respect to a fully coplanar geometry, has been reported for the $\mathrm{Ti}^{\mathrm{IV}}$ complex $\left(\mathrm{H}_{2} \mathrm{O}\right)_{2}\left(\mathrm{O}_{2}\right) \mathrm{Ti}$ (dipic) [21].

From Fig. 1 it is apparent that the dipicolinate ligand, with its rather small chelate bite angle of about $70^{\circ}$, is almost ideally suited to induce a pentacoordinate geometry even at a $\left(\mathrm{C}_{5} \mathrm{H}_{5}\right)_{2} \mathrm{Ti}$ centre, which otherwise appears to avoid this increase in coordination number, probably for steric reasons.

In line with this view, we find that $\left(\mathrm{C}_{5} \mathrm{H}_{5}\right)_{2} \mathrm{Ti}(\mathrm{dipic})$ and $\left(\mathrm{CH}_{3}\right)_{4} \mathrm{C}_{2}\left(\mathrm{C}_{5} \mathrm{H}_{4}\right)_{2} \mathrm{Ti}$ (dipic) are quite inert to ligand exchange reactions. While tetracoordinate titanocene bis-carboxylates $\left(\mathrm{C}_{5} \mathrm{H}_{5}\right)_{2} \mathrm{Ti}(\mathrm{OOCR})_{2}$, are rapidly hydrolysed upon contact with water [31], hydrolysis of $\left(\mathrm{C}_{5} \mathrm{H}_{5}\right)_{2} \mathrm{Ti}$ (dipic) in mixed aqueous solvents, such as $\mathrm{H}_{2} \mathrm{O} / \mathrm{THF}$ or $\mathrm{H}_{2} \mathrm{O}$-saturated $\mathrm{CHCl}_{3}$ proceeds at a remarkably low rate, with half-lives of about 4-5 days at $20^{\circ} \mathrm{C}$.

Even conversion into $\left(\mathrm{C}_{5} \mathrm{H}_{5}\right)_{2} \mathrm{TiCl}_{2}$ by treatment with gaseous $\mathrm{HCl}$ in $\mathrm{CHCl}_{3}$, which is practically instantaneous for other titanocene bis-carboxylate derivatives, requires about $30 \mathrm{~min}$ to go to completion with $\left(\mathrm{C}_{5} \mathrm{H}_{5}\right)_{2} \mathrm{Ti}(\mathrm{dipic})$. This would indicate that neither associative nor dissociative ligand exchange reaction modes are easily accessible for a rather rigidly connected pentacoordinate species such as $\left(\mathrm{C}_{5} \mathrm{H}_{5}\right)_{2} \mathrm{Ti}$ (dipic).

\section{Experimental}

All operations were conducted under $\mathrm{N}_{2}$ in Schlenk-type equipment.

1. $\left(\mathrm{C}_{5} \mathrm{H}_{5}\right)_{2} \mathrm{Ti}$ (dipic). A solution of dimethyltitanocene [32], $\left(\mathrm{C}_{5} \mathrm{H}_{5}\right)_{2} \mathrm{Ti}\left(\mathrm{CH}_{3}\right)_{2}$ (416 mg, $2.0 \mathrm{mmol}$ ) in $5 \mathrm{ml}$ of dry toluene is slowly added, at room temperature, to a suspension of $334 \mathrm{mg}(2.0 \mathrm{mmol})$ of dipicolinic acid in $50 \mathrm{ml}$ of dry tetrahydrofuran. The mixture is stirred for about $1 \mathrm{~h}$, during which the dipicolinic acid dissolves with evolution of $\mathrm{CH}_{4}$, to form a clear orange solution. The solution is evaporated to dryness and the residue taken up in ca. $15 \mathrm{ml}$ of toluene. After addition of hexane to the point of precipitation, and cooling to $-80^{\circ} \mathrm{C}, 423 \mathrm{mg}$ (62\% theoretical yield) of $\left(\mathrm{C}_{5} \mathrm{H}_{5}\right)_{2} \mathrm{Ti}$ (dipic) are obtained as a yellow powder, which is quite soluble in $\mathrm{CHCl}_{3}$, toluene or THF. The material is identified from its ${ }^{1} \mathrm{H}$ NMR spectrum (Table 1), its mass spectrum (with molecular ion at $m / e 343$ and appropriate isotope distribution), and by its crystal and molecular structure. 
2. $\mathrm{C}_{2}\left(\mathrm{CH}_{3}\right)_{4}\left(\mathrm{C}_{5} \mathrm{H}_{4}\right)_{2} \mathrm{Ti}($ dipic). An analogous reaction starting from $290 \mathrm{mg}$ (1 mmol) $\mathrm{C}_{2}\left(\mathrm{CH}_{3}\right)_{4}\left(\mathrm{C}_{5} \mathrm{H}_{4}\right)_{2} \mathrm{Ti}\left(\mathrm{CH}_{3}\right)_{2}$ [33] and $167 \mathrm{mg}(1 \mathrm{mmol})$ dipicolinic acid yields $493 \mathrm{mg}$ (58\% theoretical yield) of $\mathrm{C}_{2}\left(\mathrm{CH}_{3}\right)_{4}\left(\mathrm{C}_{5} \mathrm{H}_{4}\right)_{2} \mathrm{Ti}$ (dipic). Identification is from its ${ }^{1} \mathrm{H}$ NMR (Table 1), and mass spectra (molecular ion at $m / e$ 425).

\section{Acknowledgements}

This work was supported by Deutsche Forschungsgemeinschaft (grant Bri 618/85), by the University of Konstanz, and by Fonds der Chemischen Industrie.

\section{References}

1 U. Thewalt in E.H.E. Pietsch, A. Kotowski and M. Becke-Goehring (Eds.), Gmelin Handbook of Inorganic Chemistry, Vol. 40, Organotitanium compounds, Part 2 and 3, Berlin, 1984.

2 R.D. Sanner, D.M. Duggan, T.C. McKenzie, R.E. Marsh and J.E. Bercaw, J. Am. Chem. Soc., 98 (1976) 8358 .

3 S.A. Cohen, P.R. Auburn and J.E. Bercaw, J. Am. Chem. Soc., 105 (1983) 1136.

4 J.H. Teuben, J. Organomet. Chem., 69 (1974) 241.

5 G.J. Olthof and F. Van Bolhuis, J. Organomet. Chem., 122 (1976) 47.

6 M.L.H. Green, J.A. McCleverty, L. Pratt and G. Wilkinson, J. Chem. Soc., (1961) 4854.

7 R.D. Wilson, T.F. Koetzle, D.W. Hart, Å. Kvick, D.L. Tipton and R. Bau, J. Am. Chem. Soc., 99 (1977) 1775.

8 R.W. Broach, A.J. Schultz, J.M. Williams, G.M. Brown, J.M. Manriquez, P.J. Fagan and T.J. Marks, Science, 203 (1979) 172.

9 S.B. Jones and J.L. Petersen, Inorg. Chem., 20 (1981) 2889.

10 M.E. Silver, O. Eisenstein and R.C. Fay, Inorg. Chem., 22 (1983) 759.

11 U. Thewalt and W. Lassser, J. Organomet. Chem., 276 (1984) 341.

12 G. Fachinetti, C. Floriani, F. Marchetti and M. Mellini, J. Chem. Soc. Dalton, (1978) 1398.

13 G. Fachinetti, C. Floriani and H. Stoeckli-Evans, J. Chem. Soc. Dalton, (1977) 2297.

14 R. Sharan, G. Gupta, R.N. Kapoor, Trans. Met. Chem., 3 (1978) 282.

15 N.K. Kaushik, B. Bhushan, G.R. Chhatwal, Trans. Met. Chem., 3 (1978) 215.

16 N.K. Kaushik, B. Bhushan, G.R. Chhatwal, Z. Naturforsch. B, 34 (1979) 949.

17 N.K. Kaushik, B. Bhushan, G.R. Chhatwal, Syn. Reactiv. Inorg. Metal-Org. Chem., 8 (1978) 467.

18 R. Sharan, G. Gupta, R.N. Kapoor, J. Less-Common Metals, 60 (1978) 171.

19 B. Bhushan, I.P. Mittal, G.R. Chhatwal, N.K. Kaushik, J. Inorg. Nucl. Chem., 41 (1979) 159.

20 A. Clearfield, D.K. Warner, C.H. Saldarriaga-Molina, R. Ropal and I. Bernal, Can. J. Chem., 53 (1975) 1622.

21 D. Schwarzenbach, Helv. Chim. Acta, 55 (1972) 2990. H. Manohar and D. Schwarzenbach, Helv. Chim. Acta, 57 (1974) 1086.

22 C.C. Ou, W.J. Borowski, J.A. Potenza and H.J. Schugar, Acta Crystallogr. B, 33, 3246 (1977).

23 S.J. Cline, S. Kallesøe, E. Pedersen and D.J. Hodgson, Inorg. Chem., 18 (1979) 796.

24 J.G. H. du Preez, H.E. Rohwer and B.J. van Brecht, J. Chem. Soc. Dalton, (1984) 975.

25 K. Wieghardt and U. Quilitzsch, Inorg. Chim. Acta, 89 (1984) L43.

26 S.J. Anderson, D.S. Brown and A.H. Norbury, J. Chem. Soc., Chem. Commun., (1974) 996.

27 J.D. Zeinstra, J.H. Teuben and F. Jellinek, J. Organomet. Chem., 170 (1979) 39.

28 J. Besançon, S. Top, J. Tirouflet, Y. Dusausoy, C. Lecomte, J. Protas, J. Organomet. Chem., 127 (1977) 153.

29 J.C. Huffman, K.G. Moloy, J.A. Marsella and K.G. Caulton, J. Am. Chem. Soc., 102 (1980) 3009.

30 M.D. Curtis, S. Thanedar and W.M. Butler, Organometallics, 3 (1984) 1855.

31 G.A. Razuvaev, V.N. Latyaeva and L.I. Vyshinskaya, Proc. Acad. Sci. USSR, Chem. Sect., 136/141 (1961) 592.

32 K. Clauss and H. Bestian, Justus Liebigs Ann. Chem., 654 (1962) 8.

33 H. Schwemlein and H.H. Brintzinger, J. Organomet. Chem., 254 (1983) 69. 